\title{
EVALUASI PENGAKUAN, PENGUKURAN, PENCATATAN DAN PELAPORAN AKTIVA TETAP MENURUT PP NO. 71 TAHUN 2010 PADA DINAS KOPERASI DAN UMKM PROVINSI SULAWESI UTARA
}

\author{
Getruida Neni Revina Najoan ${ }^{1}$, Jantje J. Tinangon ${ }^{2}$, Stanley Kho Walandouw ${ }^{3}$ \\ 1,2,3 Jurusan Akuntansi, Fakultas Ekonomi dan Bisnis, Universitas Sam Ratulangi, Jl. Kampus Bahu, Manado, \\ 95115, Indonesia \\ E-mail: neninajoan@gmail.com
}

\begin{abstract}
Fixed assets have significant contributions to governance. In the government's balance sheet, the fixed assets account is a significant and material account. fixed assets are considered important to support the implementation of government functions in terms of service to the community. Therefore, accounting treatment in the case of recognition, measurement, recording and reporting of fixed assets must comply with SAP. The purpose of this study is to evaluate whether the recognition, measurement, recording and reporting of fixed assets at the Department of Cooperatives and SMEs North Sulawesi Province is in accordance with Government Regulation No. 71 of 2010. Research Methods used are descriptive whose purpose each data collected analyzed then drawn conclusions and the type of research used is qualitative descriptive. The results showed that the recognition, measurement, recording and reporting of fixed assets Department of Cooperatives and SMEs North Sulawesi Province has been in accordance with Government Regulation No. 71 of 2010.

Keywords: Recognition, Measurement, Recording and Reporting, Fixed Assets, Governmental Accounting Standards
\end{abstract}

\section{PENDAHULUAN}

Aset tetap memiliki kontribusi yang berpengaruh besar dalam menjalankan tata kelola pemerintahan. Pengelolaan aset tetap yang tidak dilakukan dengan maksimal juga tidak dapat menunjang kegiatan pemerintah yang lebih efektif serta tidak dapat mewujudkan tujuan pemerintah yang baik. Pemerintah terutama dalam lingkup SKPD (Satuan Kerja Perangkat Daerah) memerlukan manajemen pengelolaan dalam memanfaatkan aset yang telah diperoleh, sehingga prinsip efisiensi, efektivitas, dan transparansi dapat terlaksana. Prinsip tersebut dapat berjalan baik dengan peraturan pemerintah yang telah ditetapkan.

Dalam laporan keuangan pemerintah yaitu neraca, akun - akun aset tetap boleh dikatakan akun dengan jumlah yang signifikan dan materil. Aset tetap juga adalah salah satu aset yang berperan dalam anggaran pemerintah karena mempunyai jumlah yang besar sehingga pengakuan, pengukuran, pencatatan dan pelaporan informasi aset tetap menjadi sangat penting dalam laporan keuangan suatu entitas. Namun, aset tetap adalah aset yang menunjang penyelenggaraan fungsi pemerintahan dalam pelayanan terhadap masyarakat. Maka dari itu, pengelolaan aset tetap yang baik diperlukan karena aset tetap sering menjadi sorotan auditor Badan Pemeriksa Keuangan pada saat dilakukan pemeriksaan laporan keuangan pemerintah.

Menurut Catatan Atas Laporan Keuangan Dinas Koperasi dan UMKM Provinsi Sulawesi Utara, pelaporan keuangan disusun untuk menyajikan informasi yang bermanfaat bagi para pengguna laporan dan menilai akuntabilitas dan membuat keputusan dengan menyediakan informasi mengenai kesesuaian cara dalam memperoleh sumber daya ekonomi dan alokasinya tersebut sesuai dengan anggaran yang ditetapkan peraturan perundang- 
undangan. Dengan demikian perlakuan akuntansi aset tetap yang berada di Dinas Koperasi dan UMKM Provinsi Sulawesi Utara wajib dilaporkan sesuai dengan peraturan yang ditetapkan.

Dalam penelitian terdahulu menyatakan aset tetap merupakan salah satu bagian yang penting untuk menjalankan kegiatan operasi perusahaan. Rizki ( 2016) menyatakan bahwa Tugas utama instansi pemerintah adalah memberikan pelayanan kepada masyarakat dengan sebaik-baiknya dan aset tetap merupakan hal utama dalam memberikan pelayanan tersebut. Maka dapat dikatakan aset tetap menjadi sesuatu yang sangat penting pada sebuah instansi. Dewi (2013) Aset merupakan sarana pendukung jalannya sebuah operasi suatu organisasi yang memegang peranan penting khususnya aset tetap. Aset tetap digunakan dalam kegiatan operasional dan tidak dimaksudkan untuk dijual dalam rangka kegiatan normal perusahaan.

\section{TINJAUAN PUSTAKA}

\subsection{Konsep Akuntansi}

Akuntansi merupakan ilmu dan sebuah proses kegiatan jasa, yang berfungsi untuk menyediakan informas kuantitatif atau berupa angka, terutama yang bersifat keuangan, tentang entitas ekonomi yang dimaksudkan agar berguna dalam pengambilan keputusan ekonomi dalam membuat pilihan-pilihan yang nalar di antara berbagai alternatif tindakan. Akuntansi meliputi beberapa cabang, antara lain akuntansi keuangan, akuntansi manajemen dan akuntansi pemerintahan (Dewi, 2013).

\subsection{Akuntansi Sektor Publik}

Akuntansi Sektor Publik merupakan bidang akuntansi yang mempunyai ruang lingkup lembaga-lembaga tinggi Negara dan departemen-departemen di bawahnya, pemerintahan daerah, yayasan, partai politik, perguruan tinggi, dan organisasi-organisasi non profit lainnya. Saat ini telah terdapat perhatian yang lebih besar terhadap praktek akuntansi yang dilakukan oleh lembaga-lembaga pemerintah, perusahaan milik Negara/daerah, dan berbagai organisasi publik lainnya di bandingkan dengan pada masa-masa sebelumnya. Terhadap tuntutan yang lebih besar dari masyarakat untuk dilakukan transparansi dari akuntabilitas pubik oleh lembaga-lembaga sektor publik.

\subsection{Standar Akuntansi Pemerintah Daerah}

Standar Akuntansi Pemerintahan (SAP) berisi tentang prinsip-prinsip akuntansi yang diterapkan dalam menyusun dan menyajikan Laporan Keuangan Pemerintah, yang terdiri atas Laporan Keuangan Pemerintah Pusat (LKPP) dan Laporan Keuangan Pemerintah Daerah (LKPD). Pemerintah menerbitkan peraturan mengenai akuntansi pemerintahan, yaitu Peraturan Pemerintah Nomor 24 Tahun 2005 tentang Standar Akuntansi Pemerintahan yang telah diubah dengan Peraturan Pemerintah Nomor 71 Tahun 2010 tentang Standar Akuntansi Pemerintahan.

\subsection{Sistem Akuntansi Pemerintah Daerah}

Sistem Akuntansi Pemerintah Daerah dalam permendagri No. 64 Tahun 2013 yang disingkat menjadi SAPD merupakan suatu rangkaian prosedur dan sistematik, untuk penyelenggara, peralatan dan elemen lain dalam mewujdkan fungsi akuntansi sejak analisis transaksi sampai dengan pelaporan keuangan dilingkungan organisasi pemerintah daerah. Sistem Akuntansi Pemerintah Daerah (SAPD) menurut permendagri No. 13 tahun 2006 Pasal 232 ayat 3 meliputi serangkaian prosedur mulai dari proses pengumpulan data, pencatatan, pengikhtisaran, sampai dengan pelaporan keuangan dalam rangka pertanggungjawaban pelaksanaan APBD yang dapat dilakukan secara manual atau menggunakan aplikasi komputer.

\subsection{Laporan Keuangan Pemerintah Daerah}

Elfira (2012) menyatakan pengelolaan keuangan daerah yang akuntabel dan transparan setiap satuan kerja perangkat daerah (SKPD) dan satuan kerja pengelolaan 
keuangan daerah (SKPKD) wajib menyampaikan laporan keuangan yang mencakup : Laporan Realisasi Anggaran, Neraca Keuangan Daerah, Laporan Arus Kas, dan Catatan atas Laporan Keuangan. Laporan keuangan disusun dan disajikan sekurang-kurangnya setahun sekali untuk memenuhi kebutuhan sejumlah besar pemakai.

Komponen-komponen Laporan Keuangan Sektor Publik:

1. Laporan Realisasi Anggaran (LRA)

2. Laporan Perubahan Saldo Angaran Lebih (Laporan Perubahan SAL)

3. Neraca

4. Laporan Operasional (LO)

5. Laporan Arus Kas (LAK)

6. Laporan Perubahan Ekuitas (LPE)

7. Catatan atas Laporan Keuangan (CaLK)

\subsection{Aset Tetap}

Dalam PSAP No. 7 tentang Akuntansi Aset Tetap menyatakan bahwa Aset Tetap adalah aset berwujud yang mempunyai masa manfaat lebih dari 12 bulan untuk digunakan dalam kegiatan pemerintahan atau dimanfaatkan oleh masyarakat umum. Aset Tetap adalah termasuk bagian yang sangat penting dalam pemerintah, dan karenanya signifikan dalam penyajian neraca.

Aset tetap adalah aset berwujud yang dimiliki untuk digunakan dalam produksi atau penyediaan barang atau jasa, untuk direntalkan kepada pihak lain atau untuk tujuan administratif dan diharapkan untuk digunakan selama lebih dari satu periode. (Ikatan Akuntan Indonesia, 2013: 16)

Klasifikasi aset tetap adalah sebagai berikut:

1. Tanah

2. Peralatan dan Mesin

3. Gedung dan Bangunan

4. Jalan, Irigasi dan Jaringan

5. Aset Tetap Lainnya.

6. Konstruksi dalam Pengerjaan.

\section{Pengakuan Aset Tetap}

Aset tetap diakui pada saat manfaat ekonomi masa depan dapat diperoleh dan nilainya dapat ditukar dengan handal. Di dalam PSAP No. 7 dijelaskan untuk dapat diakui sebagai aset tetap harus dipenuhi kriteria sebagai berikut:

1. Berwujud

2. Mempunyai masa manfaat lebih dari dua belas bulan

3. Biaya perolehan aset dapat diukur secara andal

4. Tujunannya bukan untuk dijual dalam kegiatan operasi normal suatu entitas; dan

5. Dilperoleh dengan tujuan untuk digunakan.

\section{Pengukuran Aset tetap}

Aset tetap dinilai dengan biaya perolehan apabila penilaian aset tetap dengan menggunakan biaya perolehan tidak memungkinkan maka nilai aset tetap didasarkan pada niali wajar pada saat perolehan.

\section{Penyusutan}

Penyusutan adalah nilai aset tetap berkurang karena disusutkan (depreciable assets) dengan alokasi yang sistematis atas nilai suatu selama masa manfaat aset yang bersangkutan. Nilai penyusutan untuk masing-masing periode diakui sebagai pengurang nilai tercatat aset tetap dalam neraca dan beban penyusutan dalam laporan operasional. Dengan berbagai metode yang sistematis penyesuaian nilai aset tetap dilakukan sesuai dengan masa manfaat. Metode penyusutan yang digunakan harus dapat menggambarkan manfaat ekonomi atau kemungkinan jasa (service potential) yang akan mengalir ke pemerintah. 


\section{Pengungkapan Aset Tetap}

Laporan keuangan harus mengungkapkan dasar penilaian yang digunakan untuk menentukan nilai tercatat dalam laporan keuangan. Pengungkapan aset tetap dalam neraca yaitu jumlah setiap klasifikasi aset atau nilai perolehan masing-masing aset serta akumulasi penyusutan aset tetap. Pengungkapan kebijakan akuntansi yang berlaku serta informasi mengenai pos-pos aset tetap

\section{METODE PENELITIAN}

\subsection{Jenis Penelitian}

Jenis penelitian ini bersifat deskriptif. Sugiyono (2013:13) menyatakan bahwa penelitian deskriptif adalah penelitian yang bertujuan untuk menyatakan suatu situasi secara sistematis dalam bidang tertentu yang menjadi pusat pemikiran peneliti secara fakta. Penelitian ini termasuk dalam penelitian kualitatif deskriptif

\subsection{Tempat Dan WaktuPenelitian}

Tempat penelitian dilakukan pada Dinas Koperasi dan UMKM Provinsi Sulawesi Utara waktu pelaksanaan penelitian dilakukan pada bulan Desember 2017 sampai bulan Januari 2018.

\subsection{Jenis Data}

Dalam penelitian digunakan dua data jenis, yaitu :

a. Data kualitatif adalah data yang disajikan secara deskriptif atau dalam bentuk uraian. Berupa data mengenai struktur organisasi, visi misi dan gambaran umum kantor Dinas Koperasi dan UMKM Provinsi Sulawesi Utara.

b. Data kuantitatif adalah data yang disajikan dalam bentu kangka-angka yaitu dalam penelitian ini data berupa Laporan Keuangan dan Catatan Atas Laporan Keuangan (CaLK).

\subsection{Sumber Data}

Sumber data yang digunakan dalam penelitian ini adalah data primer. Data primer adalah sumber data yang diperoleh peneliti secara langsung dari objek penelitian. Sumber primer ini berupa catatan hasil wawancara yang diperoleh melalui wawancara serta observasi lapangan yang dilakukan oleh peneliti

\subsection{Metode Pengumpulan Data}

a. Wawancara langsung, yaitu dengan melakukan wawancara dalam hal ini Tanya jawab dengan pihak-pihak di Bidang Keuangan.

b. Studi dokumentasi, cara pengumpulan data dengan menggunakan arsip dan dokumen-dokumen yang mendukung penelitian ini.

c. Pengamatan / observasi, yaitu meninjau dan mengamati secara langsung apa yang menjadi objek yang diteliti dan mengamati apa yang menjadi sasaran bahan pengambilan data yang sesuai dengan apa yang diperlukan.

\subsection{Metode Analisis}

Sugiyono (2013:21) menyatakan bahwa metode yang digunakan untuk menggambarkan dan menganalisis suatu hasil penelitian tetapi tidak digunakan untuk membuat kesimpulan yang lebih luas. Metode analisis yang digunakan dalam penelitian ini adalah metode analisis deskriptif dengan pendekatan kualitatif. Metode analisis ini dimulai dengan langkah mengumpulkan dan menyaring keterangan-keterangan yang diperoleh secara menyeluruh dan detail, kemudian diuraikan sehingga diperoleh gambaran yang jelas.

\section{HASIL ANALISIS DAN PEMBAHASAN}

\subsection{Hasil analisis}

Laporan keuangan Dinas Koperasi dan UMKM Provinsi Sulawesi Utara pada tahun 2016 telah disusun berdasarkan SAP PP No. 71 Tahun 2010 Berbasis akrual. Namun dalam 
penyajiannya berdasarkan Permendagri Nomor 13 Tahun 2006. Hal ini bertujuan agar pihakpihak yang berkepentingan dapat memahami terutama dalam rangka memperbandingkan antara realisasi dengan anggaran yang ditetapkan berdasarkan Perda APBD/Perubahan APBD.

Pencatatan akuntansi yang digunakan dalam laporan keuangan pemerintah Provinsi Sulawesi Utara adalah basis kas untuk pengakuan pendapatan LRA, belanja, dan Pembiayaan dalam Laporan Realisasi Anggaran, Laporan Arus Kas dan basis akrual untuk pengakuan pendapatan LO, beban dalam Laporan Operasional serta aset, kewajiban, dan ekuitas dalam Neraca.

\section{Aset Tetap}

Berdasarkan daftar aset tetap tahun 2017 yang di dapat dari simda oleh Dinas Koperasi dan Usaha Mikro Kecil Menengah Provinsi Sulawesi Utara, diketahui bahwa total aset tetap pada tahun 2016 yang dimiliki senilai Rp 1.590.471.357,-- Total aset tersebut bersumber dari penjumlahan pos-pos aset tetap yang telah diklasifikasikan sebelumnya. Adapun klasifikasi aset tetap Dinas Koperasi dan Usaha Mikro Kecil Menengah dapat dilihat pada tabel berikut :

Tabel 4.2.2 Klasifikasi Aset Tetap per 30 November 2017

\begin{tabular}{|c|l|r|}
\hline No & \multicolumn{1}{|c|}{ Kelompok Aset } & \multicolumn{1}{c|}{ Tahun 2017 } \\
\hline 1 & Tanah & $2.800 .500 .000,00$ \\
\hline 2 & Peralatan dan Mesin & $4.107 .918 .990,00$ \\
\hline 3 & Gedung dan Bangunan & $17.726 .501 .350,00$ \\
\hline 4 & Jalan, Irigasi dan Jaringan & $203.107 .000,00$ \\
\hline 5 & Aset Tetap Lainnya & $3.381 .900,00$ \\
\hline 6 & Konstruksi dan Pengerjaan & 0,00 \\
\hline \multicolumn{2}{|c|}{ Total Aset } & $\mathbf{2 4 . 8 4 1 . 4 0 9 . 2 4 0 , 0 0}$ \\
\hline
\end{tabular}

Sumber : SIMDA Dinas Koperasi dan UMKM (2017)

Tabel 4.2.2 menunjukkan klasifikasi aset tetap yang diterapkan oleh Dinas Koperasi dan UMKM Provinsi Sulawesi Utara, dimana aset tetapnya dikelompokkan kedalam pos-pos sebagai berikut:

1. Tanah

2. Peralatan dan Mesin

3. Gedung dan Bangunan

4. Jalan, Irigasi dan Jaringan

5. Konstruksi dan Pengerjaan

6. Aset Tetap Lainnya

\subsection{Pembahasan}

Hasil penelitian menunjukkan bahwa pengakuan, pengukuran, pencatatan dan pelaporan aset tetap oleh Dinas Koperasi dan UMKM Provinsi Sulawesi Utara telah sesuai dengan peraturan pemerintah yang berlaku yaitu Peraturan Pemerintah No. 71 Tahun 2010 Pernyataan Akuntansi Pemerintahan (PSAP) No. 07 tentang akuntansi aset tetap. Aset Tetap pada Dinas Koperasi dan UMKM disajikan di Neraca sesuai klasifikasi masing-masing sebesar harga perolehannya dikurangi akumulasi penyusutan dan pengungkapan informasiinformasi penting terkait aset tetap ada dalam catatan atas laporan keuangan hanya saja dalam peneliti menemukan kesalahan di dalam neraca pada pengakuan aset tetap yaitu akun aset tetap lainnya tidak dimasukkan atau tidak dicatat dalam neraca. Meskipun kesalahan tersebut tidak mempengaruhi laporan posisi keuangan (neraca) dikarenakan aset tetap lainnya tetap terhitung karena mungkin hanya ada kesalahan pelaporan sampai aset tetap lainnya tidak 
tercatat. Namun penting hal tersebut untuk tidak terjadi dimasa yang akan datang. Pada dasarnya penyajian aset tetap di dalam neraca yang diterapkan oleh Dinas Koperasi dan UMKM sesuai dengan petunjuk (contoh/format) yang tercantum dalam Peraturan Pemerintah No 71 tahun 2010. Aset tetap harus lebih dari 12 bulan, diakui menggunakan biaya perolehan, maksud pengadaan aset tetep bukan untuk dijual melainkan untuk digunakan dalam menunjang kegiatan operasional, dan aset tetap diakui pada saat transaksi atas aset tetap itu terjadi. Walaupun perlakuan aset tetap termasuk didalamnya pengakuan, pengukuran, pencatatan dan pelaporan telah sesuai dengan Peraturan Pemerintah No 71 tahun tahun 2010 tetapi permasalahan yang dihadapi dalam mengelola aset antara lain : kesalahan pencatatan, dokumentasi dan pelaporan yang tidak diungkap.

Berikut ini disajikan tabel perbandingan pengakuan, pengukuran, pencatatan dan pelaporan aktiva tetap pada Dinas Koperasi dan Usaha Mikro Kecil Menengah Provinsi Sulawesi Utara dengan Peraturan Pemerintah No. 71 tahun 2010 pernyataan No.07 tentang Aset Tetap

\section{a. Pengakuan Aset Tetap}

Tabel 4.3 Perbandingan Pengakuan Aset Tetap oleh Dinas Koperasi dan Usaha Mikro Kecil Menengah Provinsi Sulawesi Utara dengan PSAP No. 07

\begin{tabular}{|c|c|c|}
\hline PSAP Nomor 07 & $\begin{array}{c}\text { Dinas Koperasi dan UMKM } \\
\text { Provinsi Sulawesi Utara }\end{array}$ & Hasil Evaluasi \\
\hline $\begin{array}{l}\text { a. Masa manfaat } \\
\text { lebih dari } 12 \text { (dua } \\
\text { belas ) bulan. }\end{array}$ & $\begin{array}{l}\text { a. Suatu aset diakui sebagai } \\
\text { aset tetap apabila aset } \\
\text { tersebut memiliki masa } \\
\text { manfaat lebih dari dua belas } \\
\text { bulan. }\end{array}$ & $\begin{array}{l}\text { Semua aset tetap yang ada } \\
\text { di Dinas Koperasi dan } \\
\text { UMKM Provinsi Sulawesi } \\
\text { Utara mempunyai masa } \\
\text { manfaat lebih dari dua belas } \\
\text { bulan }\end{array}$ \\
\hline $\begin{array}{ll}\text { b. } & \text { Tidak } \\
& \text { dimaksudkan } \\
& \text { dalam operasi } \\
& \text { normal entitas. }\end{array}$ & $\begin{array}{l}\text { c. Maksud pengadaan aset } \\
\text { tetap bukan untuk dijual } \\
\text { melainkan suatu aset tetap } \\
\text { diperoleh dengan maksud } \\
\text { untuk digunakan dalam } \\
\text { menunjang kegiatan } \\
\text { operasional entititas. }\end{array}$ & $\begin{array}{lrr}\text { Aset } & \text { tetap Dinas } & \text { Koperasi } \\
\text { dan UMKM } & \text { Provinsi } \\
\text { Sulawesi Utara tidak } \\
\text { dimaksud kan untuk dijual }\end{array}$ \\
\hline $\begin{array}{l}\text { c. Pengakuan aset } \\
\text { tetap apabila } \\
\text { diterima dengan } \\
\text { penandatanganan } \\
\text { berita acara dan } \\
\text { terjadi perpindahan } \\
\text { hak kepemilikan } \\
\text { maka akan sangat } \\
\text { andal }\end{array}$ & $\begin{array}{l}\text { d. Aset tetap diakui pada saat } \\
\text { penandatanganan berita } \\
\text { acara penerimaan aset tetap. }\end{array}$ & 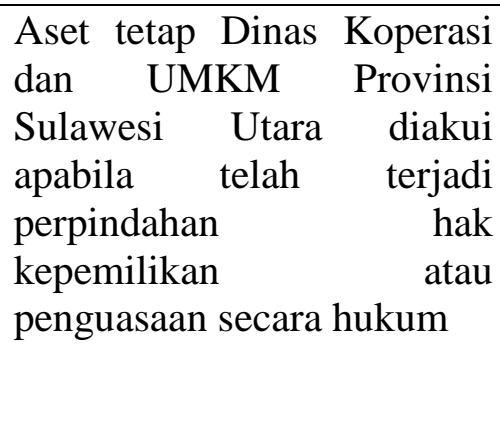 \\
\hline
\end{tabular}


b. Pengukuran Aset Tetap

Tabel 4.4 Perbandingan Pengukuran Aset Tetap oleh Dinas Koperasi dan Usaha Mikro Kecil Menengah Provinsi Sulawesi Utara dengan PSAP No. 07

\begin{tabular}{|c|c|c|}
\hline PSAP Nomor 07 & $\begin{array}{l}\text { Dinas Koperasi dan } \\
\text { UMKM Provinsi Sulawesi } \\
\text { Utara }\end{array}$ & Hasil Evaluasi \\
\hline 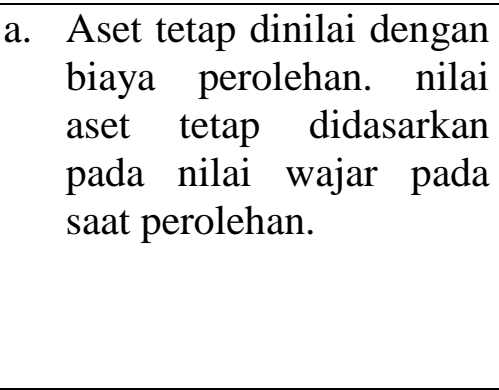 & $\begin{array}{lr}\text { a. } & \text { Biaya perolehan aset } \\
\text { tetap meliputi harga } \\
\text { beli aset tetap serta } \\
\text { biaya-biaya } & \text { yang } \\
\text { dikeluarkan } & \text { sampai } \\
\text { aset } & \text { yang } \\
\text { bersangkutan } & \text { siap } \\
\text { digunakan. } & \\
\end{array}$ & $\begin{array}{l}\text { Aset tetap pada } \text { Dinas } \\
\text { Koperasi dan UMKM } \\
\text { Provinsi Sulawesi Utara } \\
\text { diukur atau dinilai sesuai } \\
\text { dengan harga beli ditambah } \\
\text { dengan biaya-biaya yang } \\
\text { dikeluarkan sampai siap di } \\
\text { gunakan }\end{array}$ \\
\hline $\begin{array}{l}\text { b. Biaya Perolehan suatu } \\
\text { aset tetap terdiri dari } \\
\text { harga belinya, termasuk } \\
\text { bea impor dan setiap } \\
\text { biaya yang dapat } \\
\text { distribusikan secara } \\
\text { langsung. }\end{array}$ & $\begin{array}{l}\text { b. Biaya perolehan suatu } \\
\text { aset terdiri dari harga } \\
\text { beli, biaya angkut,dan } \\
\text { biaya instalasiyang } \\
\text { dikeluarkann untuk } \\
\text { aset tetap tersebut. }\end{array}$ & $\begin{array}{l}\text { Aset tetap pada Dinas } \\
\text { Koperasi dan UMKM } \\
\text { Provinsi Sulawesi Utara biaya } \\
\text { perolehan asset terdiri dari } \\
\text { harga beli biaya angkut, biaya } \\
\text { instalasi juga termasuk pajak }\end{array}$ \\
\hline
\end{tabular}

\section{c. Pencatataan dan Pelaporan Aset tetap}

Tabel 4.5 Perbandingan Pencatatan dan Pelaporan Aset Tetap oleh Dinas Koperasi dan Usaha Mikro Kecil Menengah Provinsi Sulawesi Utara dengan PSAP No. 07

\begin{tabular}{|c|c|c|}
\hline PSAP Nomor 07 & $\begin{array}{l}\text { Dinas Koperasi dan } \\
\text { UMKM Provinsi } \\
\text { Sulawesi Utara }\end{array}$ & Hasil Evaluasi \\
\hline $\begin{array}{l}\text { a. Laporan keuangan } \\
\text { harus } \\
\text { mengungkapkan } \\
\text { dasar penilaian yang } \\
\text { digunakan untuk } \\
\text { menentukan nilai } \\
\text { tercatat }\end{array}$ & $\begin{array}{l}\text { a. Pencatatan asset } \\
\text { tetap dinyatakan } \\
\text { sebesar biaya } \\
\text { perolehan aset }\end{array}$ & $\begin{array}{l}\text { Semua aset tetap pada } \\
\text { Dinas Koperasi dan } \\
\text { UMKM Provinsi Sulawesi } \\
\text { Utara dicatat di neraca } \\
\text { sebesar biaya perolehan }\end{array}$ \\
\hline $\begin{array}{lr}\text { b. Jenis-jenis } & \text { asset } \\
\text { tetap seperti } & \text { tanah, } \\
\text { gedung r dan } & \text { dangunan, peralatan } \\
\text { bangun } & \\
\text { dan mesin } & \text { dan lain } \\
\text { sebagainya } & \\
\text { dinyatakan } & \text { kedalam } \\
\text { neraca } & \text { secara } \\
\text { terpisah } & \text { atau } \\
\text { terperinci ralam } & \text { dalan } \\
\text { catatan atas laporan } & \text { keuangan }\end{array}$ & 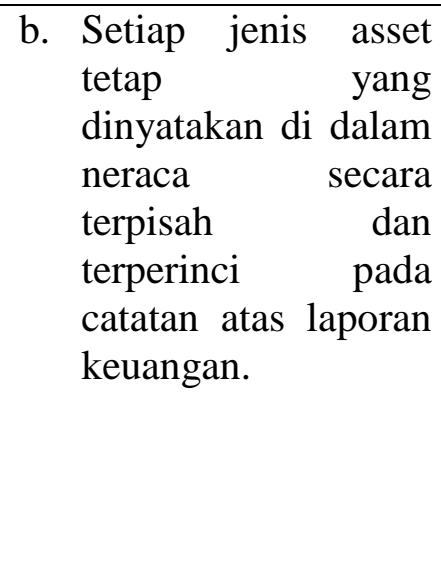 & $\begin{array}{l}\text { Semua aset tetap pada } \\
\text { Dinas Koperasi dan } \\
\text { UMKM Provinsi Sulawesi } \\
\text { Utara yang dicatat di } \\
\text { neraca secara terpisah dan } \\
\text { terperinci pada catatan atas } \\
\text { laporan keuangan }\end{array}$ \\
\hline $\begin{array}{l}\text { c. Aset tetap disajikan } \\
\text { di Neraca sebesar }\end{array}$ & $\begin{array}{l}\text { c. Aset disajikan di } \\
\text { neraca selain }\end{array}$ & $\begin{array}{l}\text { Aset tetap disajikan di } \\
\text { Neraca sebesar harga }\end{array}$ \\
\hline
\end{tabular}




\begin{tabular}{|c|c|c|}
\hline PSAP Nomor 07 & $\begin{array}{c}\text { Dinas Koperasi dan } \\
\text { UMKM Provinsi } \\
\text { Sulawesi Utara }\end{array}$ & Hasil Evaluasi \\
\hline $\begin{array}{l}\text { harga perolehan dan } \\
\text { dikurangi akumulasi } \\
\text { penyusutan dan juga } \\
\text { disajikan dalam } \\
\text { laporan realisasi } \\
\text { anggaran }\end{array}$ & $\begin{array}{lr}\text { disajikan } & \text { di } \\
\text { neraca } & \text { juga } \\
\text { disajikan } & \text { dalam } \\
\text { laporan realisasi } \\
\text { anggaran } \\
\text { mengenai } \\
\text { pembebanan asset } \\
\text { tetap }\end{array}$ & $\begin{array}{lr}\text { perolehannya } & \text { dikurangi } \\
\text { dengan } & \text { akumulasi } \\
\text { penyusutan, } & \text { selain } \\
\text { disajikan di neraca aset } \\
\text { tetap juga disajikan dalam } \\
\text { laporan realisasi anggaran. } \\
\text { Laporan realisasi anggaran } \\
\text { memberikan } & \text { informasi } \\
\text { mengenai pembebanan } & \text { para } \\
\text { aset tetap pada } & \text { anggara } \\
\text { dimana } & \text { rencana } \\
\text { peningkatan } & \text { program } \\
\text { dengan } & \text { kegiatan } \\
\text { pengadaan aset disusun } \\
\text { berdasarkan } \\
\text { dan kondisi perekonomian } \\
\text { daerah }\end{array}$ \\
\hline
\end{tabular}

\section{KESIMPULAN DAN SARAN}

\subsection{Kesimpulan}

Berdasarkan hasil penelitian dan pembahasan tentang pengakuan, pengukuran, pencatatan dan pelaporan aktiva tetap pada Dinas Koperasi dan UMKM Provinsi Sulawesi Utara dapat ditarik kesimpulan yaitu :

1. Pengakuan aset tetap Dinas Koperasi dan UMKM Provinsi Sulawesi Utara telah sesuai dengan Peraturan Pemerintah No. 71 Tahun 2010 Pernyataan Standar Akuntansi Pemerintah (PSAP) No. 07 tentang akuntansi aset tetap; Aset tetap diakui pada nilai perolehannya, baik aset tetap yang berasal dari pembelian maupun pengadaan aset tetap.

2. Pengukuran aset tetap Dinas Koperasi dan UMKM Provinsi Sulawesi Utara telah sesuai dengan Peraturan Pemerintah No. 71 Tahun 2010 Pernyataan Standar Akuntansi Pemerintah (PSAP) No. 07 tentang akuntansi aset tetap; Pengukuran aset tetap didasarkan pada harga perolehan aset tetap. Pada saat perolehan apabila tidak memungkinkan didasarkan pada harga perolehan maka penilaian aset tetap didasarkan pada harga wajar sesuai dengan ketentuan maupun kesepakatan pada saat perolehan aset tetap.

3. Pencatatan dan Pelaporan aset tetap Dinas Koperasi dan UMKM Provinsi Sulawesi Utara telah sesuai dengan Peraturan Pemerintah No. 71 Tahun 2010 Pernyataan Standar Akuntansi Pemerintah (PSAP) No. 07 tentang akuntansi aset tetap; Aset tetap disajikan di Neraca sebesar harga perolehannya dikurangi dengan akumulasi penyusutan, selain disajikan di neraca aset tetap juga disajikan dalam Laporan Realisasi Anggaran. Laporan Realisasi Anggaran memberikan informasi mengenai pembebanan aset tetap pada anggara dimana rencana peningkatan program dengan kegiatan pengadaan aset disusun berdasarkan kebutuhan dan kondisi perekonomian daerah.

\subsection{Saran}

Berdasarkan pada penelitian yang dilakukan dan hasil kesimpulan yang telah diperoleh, secara umum pengakuan, pengukuran, pencatatan dan pelaporan aktiva tetap dalam penerapannya sudah baik sesuai dengan peraturan pemerintah yang ada walaupun 
terdapat kekeliruan/kesalahan dalam pencatatan dan pelaporan. Maka saran penulis untuk tetap mempertahankan dan meningkatkan pengelolaan keuangan dan juga untuk lebih teliti dalam melakukan pengelolaan keuangan terutama pada pos aset tetap dan pos-pos lainnya agar menghasilkan laporan keuangan yang dapat diandalkan.

\section{DAFTAR PUSTAKA}

David Imanuel Tumarar, 2015. Analisis Penggunaan, Penatausahaan Dan Pemanfaatan Barang Milik Daerah Pada Dinas Pendapatan, Pengelolaaan Keuangan Dan Barang Milik Daerah Di Pemerintahan Kota Manado. Jurnal Emba. Vol 3, No 4

Dewi, 2013. Evaluasi Pencatatan dan Pelaporan Aset Tetap Pemerintah Daerah Pada Badan Pengelolaan Keuangan Dann Aset Daerah (BPKAD) Kota Kendari. Jurnal Akuntansi (Jak)

Ely Suhayati dan Sri Dewi Anggadini, 2013. Akuntansi Keuangan. Yogyakarta: Graha Ilmu. Elfira Retor, 2012. Analisis Sistem Pelaporan Belanja Langsung pada Dinas Pekerjaan Umum Pemerintah Kabupaten Minahasa Selatan. Skripsi (tidak dipublikasikan). Fakultas Ekonomi dan Bisnis Universitas Sam Ratulangi Manado.

Ikatan Akuntansi Indonesia, 2015. Standar Akuntansi Keuangan. Jakarta : Salemba Empat Leyvi, 2016. Evaluasi Penerapan Akuntansi Aset Pada Dinas Kesehatan Provinsi Sulawesi Utara. Jurnal Emba Vol 16, No 4

Mahmudi, 2013. Manajemen Kinerja Sektor Publik. Sekolah Tinggi IlmuManajemen YKPN, Yogyakarta.

Mardiasmo, 2013, Akuntansi Sektor Publik. Cetakan Keempat. Penerbit Andi, Yogyakarta.

Muslich, 2014. Teknik Pelaporan Keuangan, edisi ketiga, Yogyakarta

Melku Setargew, 2017. An Assessment On The Accounting Treatment Of Fixed Assets In The Case Of International Ngos Operating In Ethiopia St.Mary's University

Nida, 2016. Akuntansi Aset Tetap (PSAP 07) Pada Dinas Pendapatan Daerah Provinsi Kalimantan Timur. Ejurnal Untag Vol 5, No 3

Peraturan Pemerintah Republik Indonesia Nomor 71 Tahun 2010. Standar Akuntansi Pemerintahan. Lembaran Negara Republik Indonesia Tahun 2010 Nomor 123, Tambahan Lembaran Negara Republik Indonesia Nomor 5165. Sekretariat Negara. Jakarta

Pernyataan Standar Akuntansi Pemerintahan No. 07. Tahun 2010. Akuntansi Aset Tetap. Presiden Republik Indonesia. Lembaran Negara Republik Indonesia Tahun 2010, No. 123. Sekretariat Negara. Jakarta

Peraturan Menteri Dalam Negeri Nomor 13 Tahun 2006. Tentang Pedoman Pengelolaan Keuangan Daerah. Lembaran Negara Republik Indonesia Tahun 2006, No. 59. Sekretariat Negara. Jakarta

Peraturan Menteri Dalam Negeri Nomor 64 Tahun 2013. Penerapan Standar Akuntansi Pemerintahan Berbasis Akrual Pada Pemerintah Daerah. Lembaran Negara Republik Indonesia Tahun 2013. Sekreatariat Negara. Jakarta

Peraturan Gubernur Nomor 38 tahun 2015 tentang Kebijakan Akuntansi Pemerintah Provinsi Sulawesi Utara. Lembaran Negara Republik Indonesia Tahun 2015. Sekreatariat Negara. Jakarta

Pontoh, Winston 2013. Akuntansi Konsep dan Aplikasi. Halaman Moeka. Jakarta

Pura, Rahman 2013. Pengantar Akuntansi I Pendekatan Siklus Akuntansi. Penerbit Erlangga. Jakarta

Rizki, 2016. Analisis Perlakuan Akuntansi Aset Tetap Berdasarkan Pernyataan Standar Akuntansi Pemerintahan No 07 Pada Badan Penanggulangan Bencana Daerah Kabupaten Tegal. Politeknik Negeri Jakarta 
Sugiyono, 2013. Metode Penelitian Bisnis (Pendekatan Kuantitatif, Kualitatif dan R\&D). Alfabeta. Bandung.

Suwardjono, 2013. Teori Akuntansi Perekayasaan Pelaporan Keuangan. Yogyakarta : BPFE.

Tanjung, Abdul Hafiz. 2012. Akuntansi Pemerintahan Daerah Berbasis Akrual. Alfabet, Bandung. 